\title{
EFFECT OF EXTRACTION SYSTEMS ON QUALITY CHARACTERISTICS OF EXTRA VIRGIN OLIVE OIL
}

\author{
Abd El-Hamied ${ }^{1 *}$ W.A., Girgis ${ }^{1}$ A.Y. and Magda H. Allam ${ }^{2}$ \\ 1- Oils and Fats Res. Dept., Food Technol. Res. Institute, Agric. Res. Center, Giza, Egypt \\ 2- Food Sc. Dept., Fac. of Agric., Ain Sham Univ., P.O. Box 68, Hadayek Shubra 11241, \\ Cairo, Egypt
}

${ }^{*}$ Corresponding author: waelheb waelheb@yahoo.com

Received 3 September, 2019

Accepted 13 October, 2019

\begin{abstract}
The influence of extraction systems (press, two- and three-phases) on the quality of olive oils extracted from two olive oil varieties (Coratina and Koronakii) was studied. Refractive index (RI), free acidity, peroxide value, specific coefficients of extinctions ( $\mathrm{K}_{232}, \mathrm{~K}_{270}$ and $\Delta \mathrm{K}$ ), natural antioxidant content, fatty acids composition, oxidative stability and antioxidant activity were determined as well as sensory analysis was done. From the obtained results, it could be noticed that there were no significant differences among olive varieties and extraction techniques in view of oils values; refractive index and unsaponifiable matters which appeared to be approximately the same. Also, results observed that there were slight differences in fatty acids composition, depending on the extraction technique and varieties employed. While, revealed that the extraction systems had significant effect on most chemical characteristics and oxidative stability of oils due to the differences in their natural antioxidants content which was higher in oils extracted by the two-phases and press systems than in that extracted by three-phase system. The sensory evaluation and the overall quality index indicated that olive oil obtained by two-phase system was the preferable among other oils obtained by press and three-phases; it received significantly the highest scores in all the judged quality attributes. Also, the total polyphenols were higher in the extra virgin olive oils obtained by the two-phase and press systems than in that obtained by threephase system because the former two systems do not require the addition of water to olive paste in the decanter whilst, in the three-phases system water must be added to olive paste. The data re-
\end{abstract}

vealed that the best extraction system was the twophases system which produced high quality olive oil with high content of total polyphenols and that made it more resistant for oxidation during storage. Results also showed that Coratina variety gave oil with higher resistant to oxidation and higher sensorial score than oil extracted from Koronakii variety.

Keywords: Olive oil; Extraction systems; Press; Two- and Three-phase systems; Sensory evaluation; Oxidative stability; Fatty acids; Antioxidant activity

\section{INTRODUCTION}

Olive tree (Olea europaea L.) is known as the oldest cultivated tree in the world. Olive oil is extracted from the olive fruits by physical or mechanical processes that include crushing of olive fruits, malaxation of olive paste, and solid-liquid separation by pressure or centrifugation (Bejaoui et al 2016). Quality of olive oil is influenced by several different factors, including the geographical origin (Mailer et al 2010), the ripening stage (Vichi et al 2010), the soil features (Garcia-Ruiz et al 2009), the olive cultivar (Giuffrè, 2013), the agronomic techniques (Rondanini et al 2011) and the extraction process (Di Giovacchino et al 2002; Alcázar Román et al 2014), suggesting that the oil antioxidant content is not constant (Allalout et al 2009). Moreover, processing includes milling, paste malaxation and separation of oil phase, also has a major role in its chemical composition (Louadj and Giuffrè, 2010). The best commercial grades of olive oils (extra virgin and virgin) produced by mechanical procedures (Ben Brahim et al 2015), preserve the unique composition and delicate aroma of oil, and therefore can be consumed without further treatments (Boskou, 2007). 
Extra virgin olive oil (EVOO) is one of the main components of the Mediterranean diet and has attracted increasing interest from the scientific community, due to its delicate flavor, stability and widely known health benefits, which have been related both to its well-balanced fatty acids composition; oleic acid is the main component in the fatty acids and to the presence of bioactive compounds, it is a source of antioxidants such as phytosterols, carotenoids, tocopherols and phenols (Jiang et al 2015 and Fortini et al 2016), and poses positive effects on human health (Carrióna et al 2016). Moreover, the presence of polyphenols makes important contribution to its sensory characteristics and shelf life, it's also provides protective action against cancer, cardio metabolic, inflammatory, allergic, microbial and neurodegenerative diseases (Farr et al 2012).

Olive oils antioxidant capacity is stable due to its high monounsaturated with low polyunsaturated fatty acids content and the presence of phenolic compounds having a catechol group, such as hydroxytyrosol. These compounds play an important role in sensory attributes related to bitterness and pungency (Peres et al 2016).

Various techniques of oil extraction are used, including traditional press, two- and three-phase systems (Torres and Maestri, 2006). Press technique might be considered as the oldest process for obtaining olive oil, this method does not need addition of water to the olive paste. Also, this system has disadvantages such as discontinuity of the process, oil contamination diaphragms and high labor cost (Ayoub, 2006). Three-phase decanters require adding water to the system that dilutes out water soluble components resulting in the separation of the paste into three phases; oil, pomace and wastewater. One of the disadvantages of the three-phase system is the production of a considerable amount of wastewater which has a negative effect on the environment (Torres and Maestri, 2006). Two-phase decanters are used very small quantities of water which are added to dilute olive paste and produces oils with high contents of polyphenols that makes them more resistant to oxidation during storage (Di Giovacchino, 1996).

The main objective of this paper is to investigate the effect of extraction systems on quality parameters of olive oil produced and its stability.

\section{MATERIALS AND METHODS}

\section{Olive fruits}

Two varieties of olive fruits (Olea europaea L.), Coratina and Koronakii cultivars, were harvested at the end of November 2018, from Atlas Farm in Wady El-Netron, Behira Governorate, Egypt, and transported at the same day oil extraction.

All chemicals, reagents and solvents used in this study were of analytical grade and obtained from Sigma agent, USA and Corneal Lab Companies in Egypt.

\section{Extraction systems of oil: Three systems were done as follows}

\section{- Press system}

Olive fruits (Coratina and Koronakii) were separately cleaned, leaves were removed and then the olives were washed, milled of olive fruits were performed using manual experimental crusher mill to obtain a fine paste, and pressed using hydraulic laboratory Carver press. The resulting liquid phase was put into a separator funnel and allowed to settle for around $50 \mathrm{~min}$. The upper oil layer was decanted, dried over anhydrous sodium sulphate and then filtered through Whatman No.1 filter paper.

\section{- Two-phases system}

Oil was immediately extracted from olive fruits (Coratina and Koronakii) separately by the continuous two-phase decanter extraction system at Food Tech. Res. Institute, Agricultural Research Center, Giza, Egypt.

\section{- Three-phases system}

Olive fruits (Coratina and Koronakii) were separately processed at Atlas Factory for Edible Oils, Bahira Governorate, Egypt, by the continuous three-phases decanter extraction system.

The obtained oils from all the aforementioned extraction systems were kept in brown glass bottles and stored at $-18^{\circ} \mathrm{C}$, until their analyses. 


\section{Analytical Methods}

\section{Quality characteristics of extracted oils}

- Refractive index was determined according to the method described by AOAC (2016) using Abbe refractometer (NY RL-3-Poland), and the obtained results were standardized at $25^{\circ} \mathrm{C}$.

Free acidity (as oleic acids \%), peroxide value (meq. $\mathrm{O}_{2} / \mathrm{kg}$ oil), unsaponifiable matters (\%) and K232, K270 extinction coefficients calculated from absorbance at 232, $270 \mathrm{~nm}$, respectively using an UV Spectrophotometer (JENWAY 6405 UV/Vis, Spectrophotometer, England) using a $1 \%$ solution of oil in cyclohexane were determined according to AOAC (2016). The UV absorption was also read at 266 and $274 \mathrm{~nm}$ to calculate the absorption coefficient $\Delta K$ according to IOC (2001) as follows:

$$
\Delta K=K 270-[(K 266+K 274) / 2]
$$

- Organoleptic test was determined for oils extracted from the two olive fruit varieties according to the International Olive Council (IOC, 2009) by ten Qualified panelists by IOC from staff members of Fats and Oils Res. Dept., Food Technol. Res. Institute. Each panelist was asked to score fruity, bitter, pungent and defects of oils each on a hedonic scale from zero to ten.

- The overall quality index (OQI) was introduced by the International Olive Oil Council (IOOC) in 1990 to express virgin olive oil quality numerically according to the following equation:

$$
\begin{gathered}
O Q I=2.55+0.91 S E-0.78 F A-7.35 K 270- \\
0.066 P V
\end{gathered}
$$

Where: SE: sensory evaluation "fruity attribute"; FA: free acidity; K270: absorbance at $270 \mathrm{~nm}$; PV: peroxide value

\section{Fatty acids composition of olive oils}

Gas chromatography (Agilent 6890) was used for determination the fatty acids composition (\%) of olive oil samples according to the method of Cossignani et al (2005). All GC measurements for each oil sample were made in triplicate and the average values were reported.

\section{Determination of total Tocopherols}

Total tocopherols content was determined in olive oil samples according to the method of Wong et al (1988) and expressed as $\mathrm{mg} / \mathrm{kg}$ of oil.

\section{Determination of chlorophyll and carotenoids pigments}

Chlorophyll and carotenoids were determined in oils by their absorption at 670 and $472 \mathrm{~nm}$, respectively, using a Spectrophotometer (JENWAY 6405 UV/Vis., England) according to MinguezMosquera et al (1991). Results were expressed as $\mathrm{mg} / \mathrm{kg}$ oil of pheophytin and $\beta$-carotene for chlorophyll and carotenoids, respectively.

\section{Determination of total phenols}

Total phenols (TP) content of the methanolic extract of olive oil were determined by measuring the absorption at $725 \mathrm{~nm}$ using Spectrophotometer (JENWAY 6405 UV/Vis., England) according to Folin- Ciocalteu method (Gamez-Meza et al 1999). Results were expressed as mg Gallic acid/100g oil.

\section{Determination of total flavonoids content}

Total flavonoids content was determined in methanolic extract of oil by its absorption at 440 nm, using a Spectrophotometer (JENWAY 6405 UV/Vis., England) and results were calculated as mg Quercetin Equivalents (QE)/kg of oil (Kumaran and Karunakaran, 2007).

\section{Oxidative stability}

Oxidative stability of the extracted oils was evaluated by Rancimat method (Gutierrez et al 2002). Stability was expressed as the induction time (hours), measured with the Rancimat 679 apparatus (Metrohm Co., Switzerland), using an oil sample of $5 \mathrm{~g}$ heated to $100^{\circ} \mathrm{C}$ with air flow rate of $20 \mathrm{~L} / \mathrm{h}$.

\section{Antioxidant activity}

One hundred $\mu \mathrm{l}$ of methanolic extract of olive oil extract was mixed with $900 \mu \mathrm{l}$ of $60 \mu \mathrm{M}$ DPPH solution. The reaction mixture was vortexed and put in dark for about $30 \mathrm{~min}$. Absorbance was measured at $517 \mathrm{~nm}$ using a Spectrophotometer (JENWAY 6405 UV/Vis., England). Antiradical activity was expressed as inhibition percentage as mentioned by Lesage-Meessen et al (2001).

\section{Statistical analysis}

The obtained data were exposed to Statistical Analysis User's Guide (SAS, 1999). Duncan's multiple range tests at $5 \%$ level of significance was used for comparison between means. 


\section{RESULTS AND DISCUSSION}

The European regulations (EC, 1991) and the International Olive Council (IOC, 2013) have defined the olive oil quality, based on several parameters such as; free acidity content, peroxide value (PV), specific extinction coefficients (K232 and K270) and organoleptic evaluation. Some parameters are not included in the IOC, 2013 and EC standards, 1991, like phenolic content, which known for having a significant effect on the olive oil stability and its sensory attributes.

\section{Effect of extraction systems on some quality parameters of olive oils}

From results in Table (1), it could be noticed that there were no significant differences among olive varieties and extraction techniques in view of oils values; refractive index which appeared to be approximately the same. However, the free acidity content, the peroxide value, $\mathrm{K}_{232}, \mathrm{~K}_{270}$ and $\Delta \mathrm{K}$ of all analyzed samples were statistically affected, yet their values were keeping within the accepted values for extra virgin olive oils established by the European Commission Regulation (EU, 2013), (IOC, 2016) and (ESS, 2016).

The acidity of oils extracted by the press $(0.63$, $0.68 \%$ ) and three-phases (0.52, $0.65 \%)$ systems were higher than those found in oils extracted by the two-phases system $(0.29,0.39 \%)$ for the two olive varieties (Coratina and Koronakii), respectively. These increments may be due to the addition of exceeding water in three-phases system more than in two-phases, likewise the oil from press system remains with the vegetable water together till separating by settling, which therefore can promote the triglycerides hydrolysis and release free fatty acids as mentioned by Torres and Maestri (2006). Free acidity values for all oils extracted with the three systems were compatible with IOC (2016) and (ESS, 2016); they were less than $0.8 \%$ as oleic acid for EVOO.

Peroxide values (PV) of extracted oils by press and three-phases systems from the two varieties varied from 7.53 to 10.49 meq. $\mathrm{O}_{2} / \mathrm{kg}$ oil. These values were significantly higher than those of oils extracted by the two-phases system which were in the range of $5.91-6.59 \mathrm{meq} . \mathrm{O}_{2} / \mathrm{kg}$ oil. These findings may due to the higher content of natural antioxidants (Table 2) in oils obtained by press and two-phase systems than in olive oil obtained from the three-phases, and also because of the no considerable amount of water which used into twophases system compared to that in the threephases system. These observations are agreed with that of Di Giovacchino et al (2002).

From the same Table, it can be found that the values of $\mathrm{K}_{232}, \mathrm{~K}_{270}$ and $\Delta \mathrm{K}$ in all extraction systems were no significantly lower in Coratina variety than those in Koronakii. These findings are related to the high content of phenols in Coratina than in Koronakii (see Table, 2). These results are similar to those reported by Salvador et al (2003).

Specific extinction coefficients (K232) were significantly higher for oil obtained from the two varieties by three-phases system than by press and two-phases system. The absorbency at 232 $\mathrm{nm}$ is measured the hydroperoxides produced as a primary stage of oxidation and conjugated dines. Values at $232 \mathrm{~nm}$ of all extracted oils for the two varieties were under the limitation of IOC (2016) and (ESS, 2016) for EVOO (less than 2.5).

Table 1. Means values of quality parameters of olive oil as affected by extraction systems

\begin{tabular}{|c|c|c|c|c|c|c|c|}
\hline \multirow{4}{*}{\multicolumn{2}{|c|}{ Parameters }} & \multicolumn{6}{|c|}{ Olive varieties } \\
\hline & & \multicolumn{3}{|c|}{ Coratina } & \multicolumn{3}{|c|}{ Koronakii } \\
\hline & & \multicolumn{6}{|c|}{ Extraction systems } \\
\hline & & Press & Two-phases & Three-phases & Press & Two-phases & Three-phases \\
\hline \multirow{3}{*}{\multicolumn{2}{|c|}{$\begin{array}{c}\text { Refractive index at } 25^{\circ} \mathrm{C} \\
\text { Free acidity (as oleic acid)\% } \\
\text { Peroxide value (meq. } \mathrm{O}_{2} / \mathrm{Kg} \text { oil) }\end{array}$}} & $1.4664^{a}$ & $1.4664^{a}$ & $1.4663^{a}$ & $1.4665^{\mathrm{a}}$ & $1.4665^{\mathrm{a}}$ & $1.4664^{\mathrm{a}}$ \\
\hline & & $0.63^{a}$ & $0.29^{c}$ & $0.52^{\mathrm{b}}$ & $0.68^{a}$ & $0.39^{c}$ & $0.65^{a}$ \\
\hline & & $7.53^{\mathrm{bc}}$ & $5.91^{d}$ & $9.16^{a}$ & $7.70^{\mathrm{b}}$ & $6.59^{\mathrm{cd}}$ & $10.49^{a}$ \\
\hline \multirow{3}{*}{ Spectrophotometric } & K232 & $1.778^{\mathrm{b}}$ & $1.484^{d}$ & $1.943^{a}$ & $1.803^{b}$ & $1.535^{\mathrm{cd}}$ & $1.996^{\mathrm{a}}$ \\
\hline & K270 & $0.190^{\mathrm{ab}}$ & $0.133^{d}$ & $0.177^{c}$ & $0.201^{a}$ & $0.154^{d}$ & $0.182^{b c}$ \\
\hline & $\Delta \mathrm{K}$ & $0.008^{a}$ & $0.001^{e}$ & $0.002^{\text {de }}$ & $0.005^{b c}$ & $0.002^{\text {de }}$ & $0.003^{\mathrm{cd}}$ \\
\hline \multicolumn{2}{|c|}{ Unsaponifiable matters \% } & $0.88^{\mathrm{ab}}$ & $0.90^{\mathrm{a}}$ & $0.81^{c}$ & $0.86^{\mathrm{b}}$ & $0.89^{a}$ & $0.78^{d}$ \\
\hline \multirow{4}{*}{ Sensory attributes } & Fruity & $4.75^{\mathrm{c}}$ & $6.50^{\mathrm{a}}$ & $5.50^{\mathrm{b}}$ & $4.25^{d}$ & $6.25^{a}$ & $5.25^{b}$ \\
\hline & Bitter & $5.10^{b}$ & $5.65^{a}$ & $4.25^{\mathrm{de}}$ & $4.50^{\mathrm{cd}}$ & $5.25^{\mathrm{ab}}$ & $4.00^{e}$ \\
\hline & Pungent & $4.25^{b}$ & $4.75^{a}$ & $3.75^{c}$ & $3.75^{c}$ & $4.50^{\mathrm{ab}}$ & $3.50^{d}$ \\
\hline & Defects & 0 & 0 & 0 & 0 & 0 & 0 \\
\hline \multicolumn{2}{|c|}{ Overall quality index (OQI) } & $4.49^{c}$ & $6.87^{a}$ & $5.24^{b}$ & $3.90^{d}$ & $6.36^{a}$ & $4.79^{c}$ \\
\hline
\end{tabular}

Means with the same letter in the same horizontal column are not significantly different at $5 \%$ level. 
As to, values at $270 \mathrm{~nm}$ and $\Delta \mathrm{k}$ values of all extracted oils from the two varieties by all systems were under the limit of established values by IOC (2016) and (ESS, 2016) for EVOO which are less than 0.22 and 0.01 , respectively. Absorbency at $270 \mathrm{~nm}$ measures the carbonylic compounds (ketones and aldehydes) produced in the secondary stage of oxidation (Kritsakis et al 2002). The low values of $\mathrm{K} 232$ and $\mathrm{K} 270 \mathrm{~nm}$ for olive oil extracted by the two-phase system were accompanied by the increment of total polyphenol content. However, the $(\Delta K)$ index is a criterion of differentiation between a bad quality virgin olive oil and refined olive oil (IOC, 2013).

From the same Table, it can be noticed that the values of unsaponifiable matter for Coratina and Koronakii oils extracted by the three systems were nearly the same.

Table (1), also summarized the sensory evaluation of the studied oils, the data indicated that olive oil obtained by the two-phases system received significantly the highest score values compared to oils obtained by the other systems.

Sensory characteristics of virgin olive oil are classified into positive and negative attributes. Data show that the responsible compounds for the negative attributes did not exist in all oils obtained by the three systems. These compounds produced as secondary products of oxidation or enzymatic reactions, as a result of the olive oil extraction from poor quality olives, or bad manufacturing and processing procedures (Khdair et al 2015).

The fruity, a positive attribute is presented in olive oil obtained by the two and three-phase systems, its intensity were much more for olive oil extracted by the two-phases system rather than the other systems. However, a lower fruity attribute was found in oil obtained by the press system due to poor decantation and prolonged contact with the vegetable water.

Bitterness, as a positive attribute in is sensory evaluations, is considered one of the most important sensory characteristics of VOO (Ogutcu and Yilmaz, 2009). Bitterness scores of oils obtained by the two-phases extraction system were the highest followed by those of oils obtained by press, while oils extracted by the three-phases system received the least score values. These results are nearly due to the high content of polyphenols in oils extracted by the press and twophase systems. Total phenolic compounds contribute to oil flavor and aroma that characterize by bitter taste of olive oil. The data revealed an association between the "bitter" and the "pungent" taste of virgin olive oil and the total polyphenol concentration. The previous findings of Salvador et al (2003) and Ogutcu et al (2013) support our findings.

Olive oil obtained by two-phases is distinguished by the highest values of The OQI, followed by the three-phase systems, indicating high quality olive oil. These results agreed with those obtained by Khdair et al (2015).

According to the sensory evaluation and chemical analyses, olive oil obtained by all systems was classified as EVOO (see Table 1).

\section{Effect of extraction systems on some natural antioxidants of olive oils}

During processing, a large amount of antioxidants is lost with the wastewater or remaining in the pomace. As shown in Table (2), the total tocopherols were significantly affected by fruit varieties and extraction systems, being higher in Coratina than in Koronakii and in oils extracted by press and two phase systems than in oils extracted by the three-phases system. However, the $\beta$ - carotene was significantly higher in oils obtained from the two and three phase systems than in oils extracted by press form the two varieties. These results are in agreement with that found the by Issaoui et al (2009).

Olive oils pigments are an important quality parameter because it is a basic attribute for classified olive oil quality and contributed in autoxidation and photooxidation mechanisms; in this respect, Minguez-Mosquera et al (1991) illustrated that chlorophylls act as prooxidants during storage in the light; meanwhile $\beta$-carotene minimizes lipid oxidation due to its light-filtering effect.

As seen in Table (2), the chlorophyll pigment content was significantly higher in oil extracted from olive fruits by centrifugation, having statistically the highest value in oil obtained by the threephase system from Coratina variety. The data also show that the oils extracted by press and twophase systems from the two varieties had significantly higher total polyphenols content than in oils extracted by the three-phases system. These differences may be attributed to the applied temperatures and the total volume of water used which caused a reduction in polyphenols through the dilution of the olive paste in separation of oil by the three-phases centrifugation system. Similar observations have been reported by Gutierrez et al (2001); Di Giovacchino et al (2002); Gimeno et al (2002). 
Table 2. Natural antioxidants content of olive oils extracted by different methods from Coratina and Koronakii varieties

\begin{tabular}{|c|c|c|c|c|c|}
\hline \multirow{2}{*}{$\begin{array}{c}\text { Extraction } \\
\text { systems of olive } \\
\text { varieties }\end{array}$} & \multicolumn{5}{|c|}{ Natural antioxidant } \\
\hline & $\begin{array}{c}\text { Total } \\
\text { tocopherols } \\
\text { (ppm) }\end{array}$ & $\begin{array}{c}\beta \text { - carotene } \\
\text { (ppm) }\end{array}$ & $\begin{array}{c}\text { Chlorophyll } \\
\text { (ppm) }\end{array}$ & $\begin{array}{c}\text { Total } \\
\text { flavonoids } \\
\text { (mg QE/kg) }\end{array}$ & $\begin{array}{c}\text { Total phenols } \\
\text { (mg Gallic acid / } \\
100 \mathrm{~g} \text { oil) }\end{array}$ \\
\hline \multicolumn{6}{|l|}{ Coratina } \\
\hline Press & $155.42^{a}$ & $2.067^{d}$ & $2.89^{d}$ & $9.39^{a}$ & $217.37^{a}$ \\
\hline Two-phases & $151.08^{a}$ & $2.827^{a}$ & $4.853^{c}$ & $10.57^{a}$ & $207.31^{a}$ \\
\hline Three-phases & $103.37^{c}$ & $2.870^{\mathrm{a}}$ & $8.009^{a}$ & $6.17^{b}$ & $160.00^{\mathrm{b}}$ \\
\hline \multicolumn{6}{|l|}{ Koronakii } \\
\hline Press & $131.44^{b}$ & $1.075^{\mathrm{e}}$ & $2.48^{d}$ & $9.70^{\mathrm{a}}$ & $161.87^{b}$ \\
\hline Two-phases & $132.53^{b}$ & $2.475^{\mathrm{c}}$ & $6.908^{\mathrm{b}}$ & $10.03^{a}$ & $159.81^{b}$ \\
\hline Three-phases & $88.91^{d}$ & $2.665^{\mathrm{bc}}$ & $6.346^{b}$ & $6.84^{b}$ & $112.18^{c}$ \\
\hline
\end{tabular}

Means with the same letter in the same vertical column are not significantly different at $5 \%$ level

Influence of extraction systems on the fatty acids composition of olive oils.

Results in Table (3), showed that there were slight differences in fatty acids composition of the extracted olive oils, depending on the extraction technique and varieties employed. The diversity of fatty acid composition covered the normal range expected for VOO (Uceda and Hermoso, 1999). Oleic, the prevalent acid in olive oil, appeared slightly higher in oils obtained by press system than by the two and three-phase systems for the two varieties. Also, minor differences in the content of Total saturated fatty acids (TSFA) and Total unsaturated fatty acids (TUSFA) of oils extracted from the two varieties obtained by all extraction systems were recorded. These results are in accordance with those stated by Salvador et al (2003) and Torres and Maestri (2006).
Effect of extraction systems on the oxidative stability and antioxidant activity of olive oils

Results in Table (4), show that the antioxidant activity of the extracted oils are resistant to oxidation due to their high content of bioactive compounds and low content of unsaturated fatty acids with high content of one double bond (oleic acid) in the fatty acids. It could be noticed that the oxidative stability recorded a positive correlation between antioxidant activity and phenolic compounds (Table 2), it means that the variations between antioxidant activities of the studied oils may be related to the phenolic contents. High content of phenols possess much great antioxidant activity to scavenge the free radicals. These observations are agreed with those of Issaoui et al (2009). 
Olive Oil

Table 3. Percentage of fatty acids profile of extracted olive oils by three different systems

\begin{tabular}{|c|c|c|c|c|c|c|}
\hline \multirow{3}{*}{ Fatty acids } & \multicolumn{6}{|c|}{ Olive varieties } \\
\cline { 2 - 7 } & \multicolumn{5}{|c|}{ Coratina } & \multicolumn{3}{c|}{ Koronakii } \\
\cline { 2 - 7 } & \multicolumn{5}{|c|}{ Extraction systems } \\
\cline { 2 - 7 } & Press & Two-phases & Three-phases & Press & Two-phases & Three-phases \\
\hline C14:0 & $0.01^{\mathrm{a}}$ & $0.01^{\mathrm{a}}$ & $0.01^{\mathrm{a}}$ & $0.01^{\mathrm{a}}$ & $0.01^{\mathrm{a}}$ & $0.01^{\mathrm{a}}$ \\
C16:0 & $12.92^{\mathrm{a}}$ & $13.41^{\mathrm{a}}$ & $13.37^{\mathrm{a}}$ & $14.55^{\mathrm{b}}$ & $14.05^{\mathrm{b}}$ & $15.23^{\mathrm{b}}$ \\
C16:1 & $0.64^{\mathrm{c}}$ & $0.88^{\mathrm{b}}$ & $0.69^{\mathrm{c}}$ & $1.18^{\mathrm{a}}$ & $0.94^{\mathrm{b}}$ & $1.24^{\mathrm{a}}$ \\
C17:0 & $0.04^{\mathrm{a}}$ & $0.04^{\mathrm{a}}$ & $0.04^{\mathrm{a}}$ & $0.04^{\mathrm{a}}$ & $0.04^{\mathrm{a}}$ & $0.06^{\mathrm{b}}$ \\
C18:0 & $0.06^{\mathrm{b}}$ & $0.06^{\mathrm{b}}$ & $0.06^{\mathrm{b}}$ & $0.06^{\mathrm{b}}$ & $0.06^{\mathrm{b}}$ & $0.09^{\mathrm{a}}$ \\
C18:1 & $2.66^{\mathrm{a}}$ & $2.43^{\mathrm{b}}$ & $2.42^{\mathrm{b}}$ & $2.36^{\mathrm{a}}$ & $2.36^{\mathrm{a}}$ & $2.59^{\mathrm{c}}$ \\
C18:2 & $73.46^{\mathrm{a}}$ & $71.87^{\mathrm{bc}}$ & $71.97^{\mathrm{bc}}$ & $72.11^{\mathrm{b}}$ & $70.70^{\mathrm{c}}$ & $69.99^{\mathrm{c}}$ \\
C18:3 & $8.35^{\mathrm{c}}$ & $9.41^{\mathrm{a}}$ & $9.62^{\mathrm{a}}$ & $8.06^{\mathrm{c}}$ & $10.00^{\mathrm{a}}$ & $9.03^{\mathrm{b}}$ \\
C20:0 & $0.75^{\mathrm{b}}$ & $0.80^{\mathrm{bc}}$ & $0.80^{\mathrm{bc}}$ & $0.68^{\mathrm{a}}$ & $0.81^{\mathrm{c}}$ & $0.84^{\mathrm{c}}$ \\
C20:1 & $0.52^{\mathrm{a}}$ & $0.50^{\mathrm{a}}$ & $0.47^{\mathrm{a}}$ & $0.48^{\mathrm{a}}$ & $0.48^{\mathrm{a}}$ & $0.48^{\mathrm{a}}$ \\
C22:0 & $0.45^{\mathrm{a}}$ & $0.45^{\mathrm{a}}$ & $0.42^{\mathrm{a}}$ & $0.34^{\mathrm{b}}$ & $0.39^{\mathrm{ab}}$ & $0.31^{\mathrm{b}}$ \\
\hline${ }^{*}$ Total SFA & $0.13^{\mathrm{a}}$ & $0.13^{\mathrm{a}}$ & $0.11^{\mathrm{a}}$ & $0.12^{\mathrm{a}}$ & $0.13^{\mathrm{a}}$ & $0.13^{\mathrm{a}}$ \\
\hline${ }^{* *}$ Total USFA & $16.28^{\mathrm{b}}$ & $16.52^{\mathrm{b}}$ & $16.42^{\mathrm{b}}$ & $17.56^{\mathrm{ab}}$ & $17.07^{\mathrm{ab}}$ & $18.50^{\mathrm{a}}$ \\
\hline
\end{tabular}

*Total saturated fatty acids.

**Total unsaturated fatty acids.

Means with the same letter in the same horizontal column are not significantly different at $5 \%$ level.

Table 4. Oxidative stability and antioxidant activity of olive oils extracted by different three systems

\begin{tabular}{|c|c|c|}
\hline $\begin{array}{c}\text { Extraction } \\
\text { systems of } \\
\text { olive } \\
\text { varieties }\end{array}$ & $\begin{array}{c}\text { Oxidative stability } \\
\text { (h) at } 100^{\circ} \mathbf{C} \\
\text { (Induction period) }\end{array}$ & $\begin{array}{c}\% \text { Inhibi- } \\
\text { tion } \\
\text { DPPH }\end{array}$ \\
\hline Coratina & $60.00^{\mathrm{b}}$ & $92.68^{\mathrm{b}}$ \\
Press & $66.00^{\mathrm{a}}$ & $96.88^{\mathrm{a}}$ \\
Two-phases & $44.60^{\mathrm{c}}$ & $80.67^{\mathrm{c}}$ \\
Three-phases & & \\
Koronakii & $42.00^{\mathrm{c}}$ & $96.02^{\mathrm{a}}$ \\
Press & $58.60^{\mathrm{b}}$ & $98.20^{\mathrm{a}}$ \\
Two-phases & $32.80^{\mathrm{d}}$ & $66.63^{\mathrm{d}}$ \\
\hline
\end{tabular}

Means with the same letter in the same vertical column are not significantly different at $5 \%$ level.

From the obtained results, it can be say that Coratina oils extracted by the three systems characterized by its higher polyphenols content than Koronakii oils, and it recorded the best oxidative stability.

\section{CONCLUSION}

It could be concluded that the two-phases extraction system of oil from the two varieties produced high quality olive oil than that obtained by press and three phase systems, wherefrom high chemical properties, rising, shelf life and high sensorial score. Results, also showed that the best olive variety gave oil with higher resistant to oxidation and higher sensorial score was Coratina than in the oil extracted from Koronakii variety. Therefore, the research encourages farmers to expand the cultivation of Coratina variety and using the two-phases extraction system to produce high quality olive oil with high oxidation stability.

\section{REFERENCES}

Alcázar Román R., Amorós J.A., Pérez de los Reyes C., García Navarro F.J. and Bravo S. 2014. Major and trace element content of olive leaves, Official Journal of the International OIive Council, OLIVA, No. 119, 1-7.

Allalout A., Krichène D., Methenni K., Taamalli A., Oueslati I., Daoud D. and Zarrouk M. 2009. Characterization of virgin olive oil from super intensive Spanish and Greek varieties grown in northern Tunisia. Sci. Hortic. 120, 7783. 
AOAC 2016. Association of Official Agriculture Chemists. Official Methods of Analysis of $20^{\text {th }}$ (ed), Pub. Maryland 20850-3250, U.S.A

Ayoub S., 2006. Olive industry in Jordan. Proceeding of the 2nd International Seminar on Olivebioteq, November 5-10, Marsala, Italy, pp. 65-71.

Bejaoui M.A., Beltrán G., Sánchez-Ortiz A. Sánchez S. and Jiménez A. 2016. Continuous high power ultrasound treatment before malaxation, a laboratory scale approach: Effect on virgin olive oil quality criteria and yield. Eur. J. Lipid Sci. Technol., 118, 332-336.

Ben Brahim S., Marrakchi F., Gargouri B. and Bouaziz M. 2015. Optimization of malaxing conditions using $\mathrm{CaCO} 3$ as a coadjuvant: $\mathrm{A}$ method to increase yield and quality of extra virgin olive oil cv. Chemlali. LWT - Food Science and Technology, 63(1), 243-252.

Boskou D. 2007. Olive oil, Chemistry and Technology. World Rev. Nutr. Dietet. Basel, Kargere, 97, 180-210. http://doi.org/10.1159/000097916

Carrióna S., Torresa L. and Castañera O. 2016. Cardiovascular risk protection from the Mediterranean diet and olive oil. A transcriptomic update in humans. Grasas Y Aceites. 67, 1-16.

Cossignani L., Simonetti M.S. and Damiani P. 2005. Biocatalyzed acidolysis of olive triacylglyceols with 9c, 11t and 10t, 12c isomers of conjugated linoleic acid. Eur Food Res. Techol. 220, 267-271.

Di Giovacchino L. 1996. Influence of extraction systems on olive oil quality. Olivae, 63, 52-63.

Di Giovacchino L., Sestili L.S. and Di Vincenzo D. 2002. Influence of Olive Processing on Virgin Olive Oil Quality. Eur. J. Lipid Sci. Technol., 104, 587-601.

Egyptian Standards Specifications 2016. Vegetable edible oils, part: 2; olive oils and olive pomace oils. ES: 49- 2, Egyptian Organization for Standardization and Quality, Egypt.

European Community 1991. Commission Regulation, 2568/91 on the characteristics of olive oil and olive residue oil and on the relevant methods of analysis. Official J. of the European Communities, July 11, L 248, 1-83.

European Union 2013. Commission Implementing Regulation (EU) No 299/2013 of 26 March, Official Journal of the European Union.

Farr S.A., Price T.O., Dominguez L.J., Motisi A., Motisi A., Saiano F., Niehoff M.L., Morley J.E., Banks W.A., Ercal N. and Barbagallo M. 2012. Extra virgin olive oil improves learning and memory in SAMP8 mice. J. Alzheimers Dis. 28, 81-92.

Fortini M., Migliorini M., Cherubini C., Cecchi L., Guerrini L., Masella P. and Parenti A. 2016. Shelf life and quality of olive oil filtered without vertical centrifugation. Eur. J. Lipid Sci. Technol. 118, 1213-1222.

Gamez-Meza N., Nriega-Rodiguez T.A., MediraJularz L.A., Ortega-Gracia J., CazarazezCasanova R. and Angulo-Guerrero O. 1999. Antioxidant activity in soybean oil of extracts from Thompson grape bagasse. JAOCS, 76, 1445-1447.

Garcia-Ruiz R., Ochoa V., Vinegla B., Hinojosa M. B., Pena-Santiago R., Liebanas G., Linares J.C. and Carreira J.A. 2009. Soil enzymes, nematode community and selected physico-chemical properties as soil quality indicators in organic and conventional olive oil farming: Influence of seasonality and site features. Appl. Soil Ecol. 41, 305-314.

Gimeno E., Castellote A.I., Lamuela-Raventós R.M., de la Torre M.C. and López-Sabater M.C. 2002. The effect of harvest and extraction methods on the antioxidant content (phenolics, $\alpha$-tocopherol, and $\beta$-carotene) in virgin olive oil. Food Chem., 78, 207-211.

Giuffrè A.M. 2013. Influence of harvest year and cultivar on wax composition of olive oils. Eur. J. Lipid Sci. Technol. 115, 549-555.

Gutiérrez F., Arnaud T. and Garrido A. 2001. Contribution of polyphenols to the oxidative stability of virgin olive oil. J. Sci. Food Agric., 81, 1463- 1470.

Gutiérrez F., Villafranca M.J. and Castellano J.M. 2002. Changes in the main components and quality indices of virgin olive oil during oxidation, J. Am. Oil Chem. Soc. 79(7), 669-676.

International Olive Oil Council 1990. Definizione dell'Indice Globale di Qualita per gli Oli di Oliva Vergini: Risultati dell'Analisi Circolare e Sua Adozione, Olivae 30, 12-15.

International Olive Council 2001. Trade standards applying to olive oil and olive-pomace oil. COI/T20/Doc. No. 19/Rev.1, International Olive Oil Council, Madrid.

International Olive Council 2009. Sensory analysis of olive oil- Method- Organoleptic assessment of virgin olive oil. RES-3/75-IV/96, Revised method for the organoleptic assessment of virgin olive oil. T.20/Doc. no. 15/Rev.1.

International Olive Council 2013. Trade Standard Applying to Olive Oils and Olive-Pomace Oils. T.15/NC No 3/Rev.7. 
International Olive Council 2016. http://www. internationaloliveoil.org

Issaoui M., Dabbou S., Brahmi F., Ben Hassine K., Hajaïj Ellouze M. and Hammami M. 2009. Effect of extraction systems and cultivar on the quality of virgin olive oils. Int. J. of Food Sci. and Technology, 44, 1713-1720.

Jiang L., Zhen H. and Lu H. 2015. Application of UV spectrometry and chemometric models for detecting olive oil-vegetable oil blends adulteration. J. of Food Science and Technology, 52(1), 479-485.

Khdair A.I., Ayoub S. and Abu-Rumman G. 2015. Effect of Pressing Techniques on Olive Oil Quality. American J. of Food Technology 10(4), 176-183.

Kritsakis A., Kanavouras A. and Kritsakis K. 2002. Chemical analysis, quality control and packaging issues of olive oil. European J. of Lipid Sci. and Technology 104, 628-638.

Kumaran A. and Karunakaran J.R. 2007. In-vitro antioxidant activities of methanol extracts of five Phyllanthus species from India, LWT Food Sci. Technol., 40(2), 344.

Lesage-Meessen L., Navarro D., Maunier S., Sigoillot J.C., Lorquin J., Delattre M., Simon J.L., Asther M. and Labat M. 2001. Simple phenolics content in olive oil residues as a function of extraction systems. Food Chemistry, 75(4), 501-507.

Louadj L. and Giuffrè A.M. 2010. Analytical characteristics of olive oil produced with three different processes in Algeria. Riv. Ital. Sostanze Grasse 87, 186-195.

Mailer R.J., Ayton J. and Graham K. 2010. The Influence of Growing Region, Cultivar and Harvest Timing on the Diversity of Australian Olive Oil. J. Am. Oil Chem. Soc. 87, 877-884.

Minguez-Mosquera M.I., Rejano L., Gandul B., Sanchez A.H. and Garrido J. 1991. ColorPigment Correlation in Virgin Olive Oil. J. of the American Oil Chemists' Society, 68, 322337.

Ögütcü M. and Yilmaz E. 2009. Path Analysis for the Behavior of Traditional Olive Oil Consumer in Çanakkale. Food Sci Technol. Res., 15(1), 9-12.

Ögütçü M., Aydeniz B. and Yılmaz E. 2013. Comparison of the virgin olive oils obtained from different points of common oil production systems. Gida, 38(2), 79-85.

Peres F., Martins L.L., Mourato M., Vitorino C. and Ferreira-Dias S. 2016. Bioactive Compounds of Portuguese Virgin Olive Oils Discriminate Cultivar and Ripening Stage. J. Am Oil Chem. Soc., 93, 1137-1147.

Rondanini D.P., Castro D.N., Searles P.S. and Rousseaux M.C. 2011. Fatty acid profiles of varietal virgin olive oils (Olea europaea L.) from mature orchards in warm arid valleys of Northwestern Argentina (La Rioja). Grasas Aceites 62, 399-409.

Salvador M.D., Aranda F., Gomez-Alonso S. and Fregapane G. 2003. Influence of Extraction System, Production Year and Area on Cornicabra Virgin Olive Oil: A Study of Five Crop Seasons. Food Chemistry, 80, 359-366.

SAS Institute Inc., 1999. Statistical Analysis System. User's Guide: Statistics, SAS Institute Inc., Editors, Cary, NC, USA.

Torres M.M. and Maestri D.M. 2006. The effects of genotype and extraction methods on chemical composition of virgin olive Oils from Traslasierra Valley (Córdoba, Argentina). Food Chemistry, 96, 507-511.

Uceda M. and Hermoso M. 1999. La calidad del aceite de oliva. In: Barranco, D., Ferna'ndezEscobar R. and Rallo L. (Eds.), El cultivo del olivo (pp. 571-596). Madrid: Ediciones MundiPrensa.

Vichi S., Lazzez A., Grati Kamoun N., LopezTamames E. and Buxaderas S. 2010. Evolution of Sesquiterpene hydrocarbons in virgin olive oil during fruit ripening. J. Agric. Food Chem. 58, 6972-6976.

Wong M.L., Timms R.E. and Cioh E.M. 1988. Colormetric determination of total tocopherols in palm oil, olein and stearin. J.A.O.C.S., 2, 258-261. 


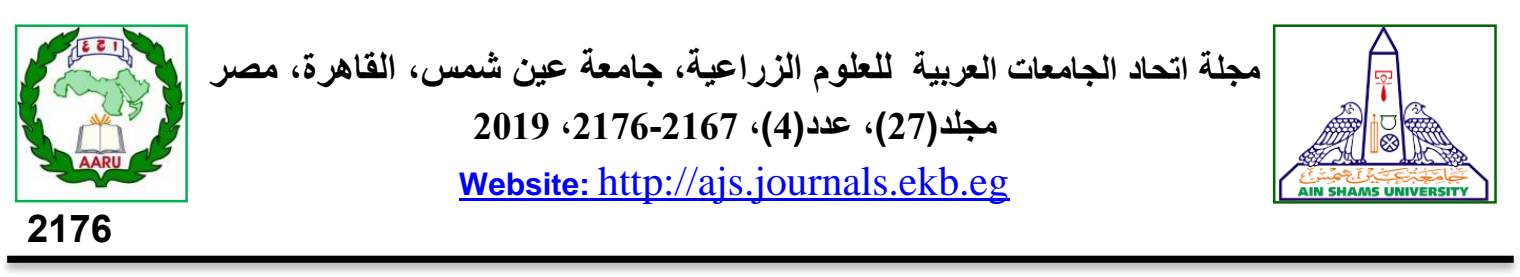

تأثير أنظمة الاستخلاص على خصائص الجودة لزيت الزيتون البكر المتاز

[172]

\author{
وائل عبد الفتاح عبد الحميد1" ـ عادل يوسف جرجس1 ـ ماجدة حبيب علام²

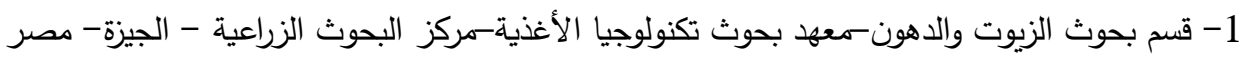 \\ 2- قسم علوم الأغذية - كلية الزراعة - جامعة عين شمس - ص.ب 68 - حدائق شبرا 11241 - القاهرة - مصر
}

*Corresponding author: waelheb waelheb@yahoo.com

Received 3 September, 2019 Accepted 13 October, 2019

بالزيوت المستخلصسة بنظام الطرد المركزى ذو الثلاثتة

مراحل.

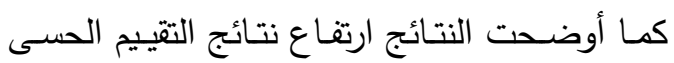

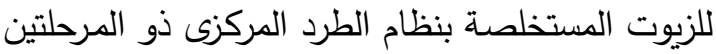

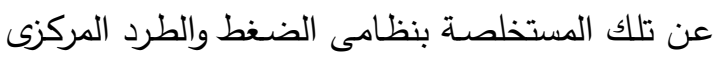

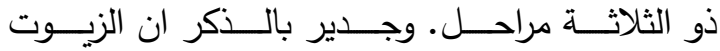

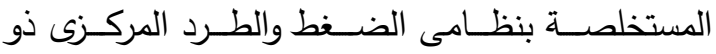

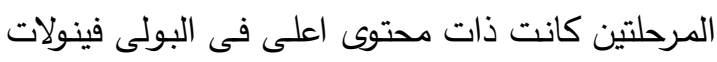

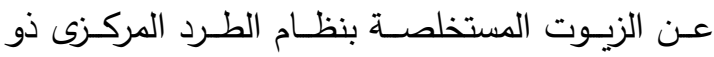

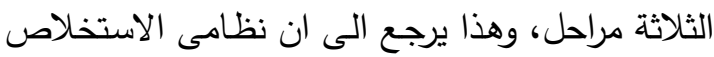

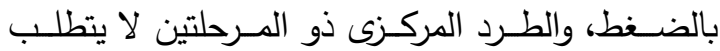

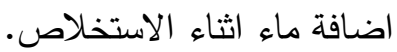
أشارت النتائج ان افضل طرق الأناص الأتخلاص لانتاج

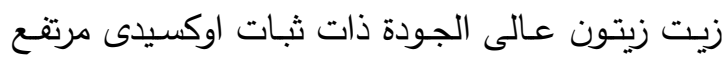
اثثاء التخزين هو نظام الاستخلاص بالطرد المركزى المستمر ذو المرحلتين.

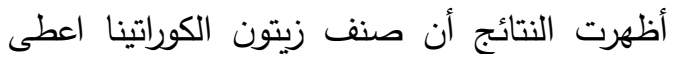
زيتا ذو صفات مقاومة للاكسدة وصفات جودة حسية

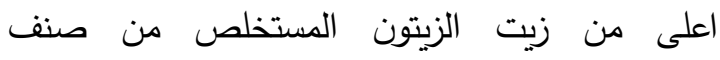

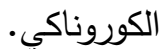

الكلمات الدالة: زيت الزيتون، طرق الاستخلاص، تقييم

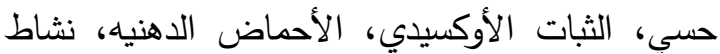

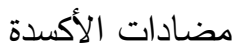

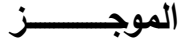

تـم دراســة تـأثير طـرق اسـتخلاص زيــت الزيتـون

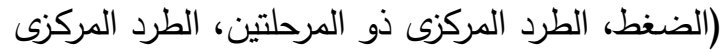

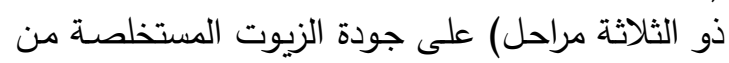
صـنفى ثمـار الزيتـون الزيتيـة (كوراتينـا، كورونـاكى).

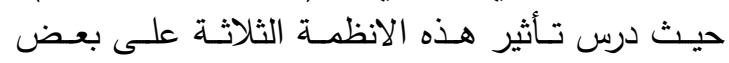

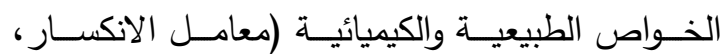

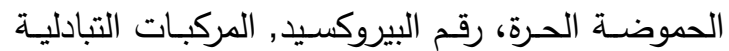

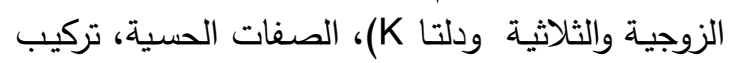

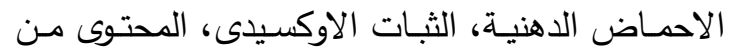

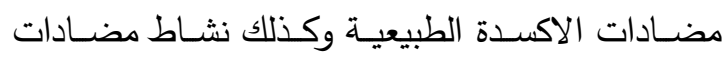

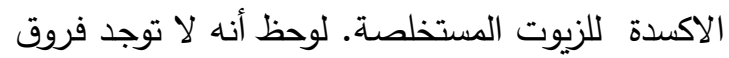

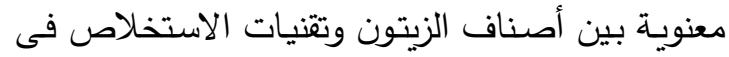

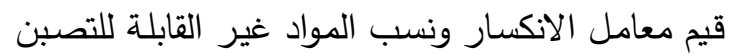

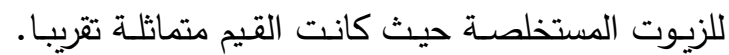

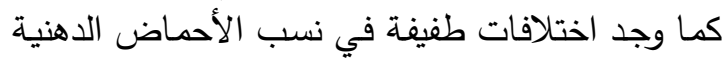

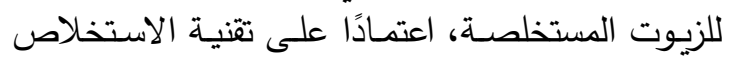
والأصناف المستخدمة. أشارت النتائج الى أن طرق الاستخلاص لها تأثير

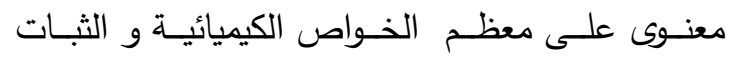

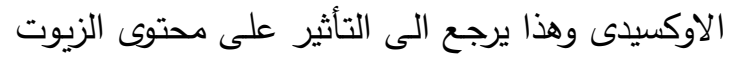

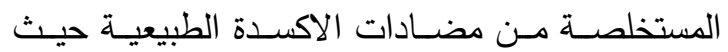

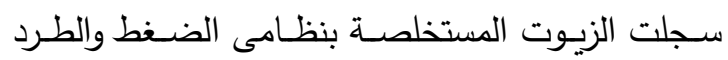

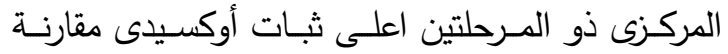


